\title{
MENYISIPKAN POLITIK HUKUM DALAM SOSIALISASI NORMA ISLAM KE DALAM SISTEM HUKUM NASIONAL
}

\author{
Jeje Abdul Rojak \\ Universitas Islam Negeri Sunan Ampel Jl. Jend. A. Yani I I 7 Surabaya \\ jejeabdulrozaq@yahoo.com
}

\begin{abstract}
Struggle to establish a sovereign state for Indonesian Muslims is final. It just fills the empty space with the various regulations needed to manage the country in a healthy way and to protect the entire people of Indonesia has not been incomplete. To solve the problems need a lot of time and energy. As a majority, Muslims have a responsibility to maintain the existence of the sovereign state of Indonesia as the application of the Islamic teachings. Synergizing between the execution of religious guidance and filling various regulations needed to manage the country are not easy, since it takes approach, strategy, and persistence in argument. That is why the legal politics is a necessity. There are at least three factors that support the Islamic law in Indonesia, namely some Islamic political parties, Islamic organizations, and formal and informal educational institutions. They can fight in the legislative space and promote themselves in the community so that Islamic norms can be inserted in various policies applied in their respective areas. Thus, Islamic norms will continue to grow in society and will not fade.
\end{abstract}

Keywords: Political Law, power, political system, Islamic norms

Abstrak: Perjuangan mendirikan negara yang berdaulat sudah final dilakukan oleh umat Islam Indonesia. Namun, mengisi ruang kosong dengan berbagai peraturan yang dibutuhkan untuk mengelola negara secara sehat dan melindungi seluruh rakyat Indonesia belum selesai. Untuk menuntaskan hal tersebut, membutuhkan waktu dan menguras energi. Umat Islam sebagai penghuni mayoritas punya tanggung jawab untuk mempertahankan eksistensi negara Indonesia yang sudah berdaulat tersebut, dengan tidak melupakan tanggung jawabnya sebagai orang yang beriman agar menjalankan ajaran Islam. Mensinergikan antara pelaksanaan tuntunan agama dan mengisi kekosongan berbagai peraturan yang dibutuhkan dalam mengelola negara ternyata tidak mudah, butuh pendekatan, strategi seni dan 
kegigihan dalam berargumen. Itulah sebabnya politik hukum sebuah keniscayaan. Sudah ada tiga faktor penopang hukum Islam di Indonesia, yaitu partai politik berbasis ideologi keislaman, organisasi masyarakat keagamaan umat Islam dan berbagai lembaga pendidikan baik formal maupun informal. Mereka dapat berjuang di ruang legislasi dan mempromosikan diri di masyarakat agar norma-norma Islam dapat disisipkan dalam berbagai kebijakan yang diterapkan di wilayah masing-masing. Dengan demikian, norma-norma Islam akan terus tumbuh di masyarakat dan tidak akan luntur.

Kata Kunci: Politik Hukum, Kekuasaan, Sistem Politik, Norma Islam

\section{Pendahuluan}

Pribumi muslim sebagai penduduk mayoritas (warga negara) Negara Kesatuan Republik Indonesia wajib bersyukur atas kegigihan perjuangan tokoh-tokoh pendahulunya yang mewariskan monumen perjuangan mereka dalam sistem kenegaraan di republik ini. Hasil perjuangan tokoh-tokoh pejuang muslim itu dapat dinikmati dalam bentuk: (1) Lembaga pendidikan Islam yang diakui negara sebagai institusi resmi dalam bentuk pendidikan formal dari usia pra-sekolah sampai puncak pendidikan tinggi setingkat strata tiga (program doktor), dan pendidikan pesantren (nonformal) sampai yang diakui formal dengan program $m u$ 'âdalah (lulusan pesantren yang diakui secara formal oleh negara); (2) Adanya Kementerian Agama dari tingkat pusat sampai KUA di tingkat kecamatan serta adanya Peradilan Agama yang secara leluasa mengurusi perkara umat Islam (walau masih masalah perdata) dan semua perangkatnya mensyaratkan Islam sebagai kriteria utama, baik personil yang menangani urusan kompetensi absolut yang menjadi tugas pokoknya atau hukum materiil yang jadi acuan menyelesaikan perkara yang ditanganinya; (3) Para takmir masjid dan mushola juga bagian dari institusi strategis umat Islam bila ditata dengan profesional dan visioner serta (4) Aset wakaf yang sudah mulai ditata, walaupun masih sulit untuk diinventarisir dan dikoordinasikan berdasarkan prinsip-prinsip kebermanfaatan dan berdaya guna untuk kemaslahatan secara maksimal dalam mensejahterakan umat. 
Di samping itu, masa lalu pribumi muslim dalam kesejarahannya sudah bisa membuktikan hasil dengan membangun kekuasaan politik dalam bentuk kerajaan (kesultanan) seperti: Samudera Pasai, Demak, Mataram, Goa, dan sebagainya dengan cara damai pula mereka mengambil alih posisi serta menyadarkan masyarakat dari Hindu-Budha menjadi beragama Islam yang tidak pernah ada catatan huru-hara atau kekejaman (kekerasan).

Bahkan ketika dihadapkan dengan datangnya kolonial Barat pun, pribumi muslim dengan gigih dapat mempertahankan tanah airnya sampai terbangunnya kesadaran untuk mendirikan negara modern dengan nama Indonesia. ${ }^{1}$ Dalam masalah ini juga kepiawaian para tokoh umat Islam diperlihatkan dengan berhasilnya asas negara Pancasila dan sistem konstitusi negara (Undang-Undang Dasar 1945) yang sejalan dengan cita-cita ajaran Islam (maqâshid al-Syariah). Hasil perjuangan itu melahirkan deklarasi bersama muslim pribumi bahwa Negara Kesatuan Republik Indonesia sebagai bentuk final bagi umat Islam dalam berjuang mendirikan negara. ${ }^{2}$ Sehingga muslim pribumi sudah tidak lagi berpikir untuk mengganti NKRI dengan bentuk negara lain, akan tetapi bagaimana bisa mengisi dan mempertahankan eksistensi NKRI serta berjuang untuk membebaskannya dari negara yang masih dikategorikan negara sedang membangun menjadi negara maju bahkan menjadi super power.

Dinamika perjuangan pribumi muslim dalam berkompetisi mengisi dan mengelola NKRI ini sepertinya cukup menarik untuk didiskusikan secara akademis, karena tantangan di era hiperkompetisi ini berbagai kepentingan selalu bertarung dengan

\footnotetext{
I Gegap gempita perjuangan pribumi muslim dalam masa-masa awal pendirian Negara Kesatuan Republik Indonesia perlu mendapat kajian secara khusus. Tulisan ini hanya memberikan gambaran awal untuk merenungkan kembali kegigihan tokoh-tokoh umat Islam.

2 Pengakuan bentuk final negara Indonesia, sebagai negara yang sah untuk umat Islam adalah keputusan muktamar NU ke-27 di Situbondo, Desember 1984, yang akhirnya juga diikuti oleh organisasi keagamaan lainnya. Lihat Imron Hamzah dan Choirul Anam, Gus Dur Diadili Kiai-kiai, (Surabaya: Jawa Pos, 1989). Baca juga Ahmad Zahro, Tradisi Intelektual NU, Lajnah Bahtsul Masail 1926- 1999, (Yogyakarta: LkiS, 2004).
} 
gigih yang disertai pula dengan perkembangan ilmu pengetahuan dan teknologi serta alat komunikasi dan sistem digital yang menjadi mindset dunia saat ini.

Masalahnya adalah bagaimana posisi pribumi muslim dalam percaturan arus era digital dan daya saing dalam mewujudkan cita-cita kemerdekaan, dan di mana meletakkan hukum Islam dalam mengisi kekosongan hukum positif yang masih diisi oleh hukum-hukum warisan kolonial. ${ }^{3}$

\section{Memetakan Hukum, Politik, dan Kekuasaan}

Keterkaitan atau (mungkin) saling ketergantungan antara politik dan hukum merupakan topik yang tidak akan pernah basi. Lebih-lebih di negara yang sedang mengalami euforia, atau di negara yang sedang mengalami krisis dan instabilitas. Dalam kondisi ini, logika hukum positif gagal untuk menjelaskan fenomena sekarang, dimana orang-orang sudah kehilangan rasa bersalah, rasa malu, dan rasa takut untuk melakukan perilaku yang tidak benar. Hukum mengalami keterpurukan yang sangat menyedihkan. Kondisi seperti ini dapat dikatakan pula hukum mengalami krisis orientasi.

Kritik terhadap orientasi kajian hukum selalu menjadi obsesi dan selalu menjadi perbincangan yang menarik. ${ }^{5}$ Lebih dari itu perlunya telaah ulang terhadap orientasi kajian ini tidak hanya

\footnotetext{
3 Untuk mendapatkan gambaran transformasi Hukum Islam dalam perkembangan hukum di Indonesia, sudah banyak kajian dari para pemerhati bahwa peluang ini cukup dominan dalam sistem hukum di negara kita. Contoh: Lihat Muhammad Daud Ali, Hukum Islam dan Peradilan Agama, (Jakarta: PT Raja Grafindo Persada, 1997), 173- 187. Tulisan ini memang agak lama tapi masih sangat relevan untuk dijadikan bahan kajian sejarah. Karena, di era tahun 1990-an dinamika perbincangan hukum Islam cukup menggembirakan terutama setelah mengembalikan marwah Peradilan Agama menjadi negara yang lainnya, dengan hadirnya UU No. 7 tahun 1989.

${ }^{4}$ Achmad Ali, Keterpurukan Hukum di Indonesia Penyebab dan Solusinya, (Jakarta: Ghalia Indonesia, 2002), 52-53.

${ }^{5}$ Achmad Qadri Azizy, dalam bukunya, Eklektisisme Hukum Nasional, Kompetisi antara Hukum Islam dan Hukum Umum, (Yogyakarta: Gama Media, 2002), memaparkan bagaimana perbincangan penerapan hukum di Indonesia sedemikian pelik, tapi tetap asyik untuk dikaji, lebihlebih kajian itu diproyeksikan dalam penerapan hukum Islam yang masih dianggap "eksklusif". (Lihat: Aziziy, 2002:87-97; I87; 199 dan 210).
} 
dirasakan di Indonesia, akan tetapi dirasakan pada hampir semua negara-negara berkembang.

Laporan yang diterbitkan oleh Persatuan Bangsa-Bangsa (PBB) 1985, lewat International Legal Center-nya berjudul Legal Education in Changing World, memberikan gambaran yang menarik serta alternatif-alternatif bagi perbaikan kajian-kajian hukum di negara-negara sedang berkembang. Di negara-negara dunia ketiga ini, kebanyakan hukum yang sedang berlaku baik hukum perburuhan, pajak dan perusahaan serta pemerintahan mengikuti hukum asing.

Sistem dan profesi hukum sampai batas tertentu adalah upaya pengalihan atau budaya hukum tertentu. Proses ini secara historis agaknya seakan-akan menjadi legitim oleh apa yang disebut "kolonialisasi" dan upaya lain yang jauh dari sikap sukarela. Kondisi ini tentu senantiasa mendorong telaah terhadap orientasi kajian hukum.

Menurut laporan Pusat Hukum PBB itu, masalah pokok yang dihadapi negara-negara berkembang adalah bagaimana mewujudkan suatu sistem hukum yang lebih sesuai dengan kepribadian bangsa, sebab hukum yang telah ada seringkali terasa asing bagi masyarakat.

Krisis orientasi kajian hukum di Indonesia sejak beberapa tahun sampai sekarang tetap dirasakan oleh kalangan yang terlibat dan penuh minat di bidang ini. Mulai dari Mochtar Kusumaatmadja menjelang dekade delapan puluhan yang ketika itu menjabat sebagai ketua sub konsorsium ilmu hukum, senantiasa menyayangkan kemampuan produk lembaga-lembaga pendidikan tinggi hukum.

Menurut Mochtar, kajian hukum di Indonesia lebih memberikan keahlian "tukang" dalam rangka penerapan aturanaturan yang telah ada. Kajian yang berdimensi sosio-kultural, ekonomi dan politik yang mempunyai kaitan amat erat dengan kajian hukum tidak mendapat tempat yang semestinya. Oleh karenanya kerap ditemui kalangan terdidik hukum yang masih 
berpendapat misalnya hukum ekonomi tidak dibutuhkan karena semua permasalahan ekonomi telah dicakup dalam kajian hukum bidang keperdataan.

Suatu pandangan yang tidak lagi pas karena dalam perkembangannya, hukum dalam bidang ekonomi di samping mengatur hubungan antara warga masyarakat dalam bentuk keperdataan, lebih dari itu mengandung kewajiban pemerintah dalam upaya melidungi kepentingan masyarakat dan kepentingan politik negara. $^{6}$

Di Indonesia, tantangan ini telah menggiring pakar hukum ke arah suatu pendekatan yang lebih komprehensif. Bagi mereka, studi hukum tidak terbatas dalam bentuk peraturan-peraturan lepas. Ia berkaitan dengan sosial, politik, dan kultur. Ia juga merupakan bagian secara masif dalam masyarakat yang terus berubah. ${ }^{7}$

Untuk mewujudkan idealisme penataan hukum, ternyata tidak bisa berdiri sendiri. Hukum akan berjalan dengan baik, manakala ditopang oleh kekuasaan. Kekuasaan diproduk oleh sistem politik. Cerminan hukum yang ideal, yang menjamin rasa keadilan bersama dan tanpa pilih kasih sangat tergantung pada konstalasi: sistem politik, kekuasaan, dan hukum itu sendiri.

\section{Korelasi Hukum dan Kekuasaan}

Mengingat bahwa hukum itu memerlukan daya paksa bagi penataan ketentuan-ketentuannya, dapat dikatakan bahwa hukum memerlukan kekuasaan bagi penegakannya. Tanpa kekuasaan, hukum akan menjadi kaidah sosial yang berisikan anjuran belaka. Padahal, hukum seperti kaidah sosial lainnya, yang juga mengenal

\footnotetext{
${ }^{6}$ Dalam kajian ini dapat dilihat bahwa peranan Presiden dan DPR dalam melahirkan UndangUndang Organik sebagai penjabaran UUD '45 tidak boleh melampaui batas-batas yang sudah digariskan oleh Undang-Undang Dasar tersebut. Lihat Azizy, Eklektisisme...., 231.

7 Kajian ini dapat diperluas dengan memperhatikan paparan Muhammad Daud Ali, "Hukum Islam dan Peradilan Agama”, (Kumpulan tulisan), (Jakarta: Raja Grafindo Persada, 1997). Ali menjelaskan dalam merumuskan perundang-undangan dan perkembangan hukum di Indonesia, harus dikaji secara cermat dari berbagai aspek, kultur, asas fundamental dan realitas ideologi yang berkembang di masyarakat. Lihat juga Achmad Ali, Keterpurukan Hukum di Indonesia..., I73- 187.
} 
Jeje Abdul Rojak

bentuk-bentuk paksaan. Dalam hal kekuasaan, memaksa itu sendiri diatur, baik mengenai cara maupun ruang gerak atau pelaksanaannya. Kita mengenal polisi, kejaksaan, dan pengadilan sebagai pemaksa atau penegak hukum negara yang masingmasing ditentukan batas wewenangnya.

Dengan demikian, hubungan hukum dan kekuasaan dalam masyarakat dapat kita simpulkan sebagai berikut: hukum memerlukan kekuasaan bagi pelaksanaannya, sebaliknya kekuasaan itu sendiri ditentukan batas-batasnya oleh hukum. Hukum tanpa kekuasaan adalah angan-angan, kekuasaan tanpa hukum adalah kelaliman. ${ }^{8}$

Kekuasaan merupakan suatu unsur yang mutlak dalam suatu masyarakat hukum, dalam artian yaitu masyarakat yang diatur oleh dan berdasarkan hukum. Secara analitik, barangkali dapat dikatakan bahwa kekuasaan merupakan suatu fungsi masyarakat yang teratur. ${ }^{9}$ Kekuasaan sering diartikan sama dengan kekuasaan fisik (termasuk senjata), dan kekuasaan itu dimiliki orang yang berwenang. Karena itu, digambarkan bahwa kekuasaaan fisik (force) dan wewenang resmi (formal authority) merupakan dua sumber kekuasaan. Kekuasaan itu adalah fenomena yang aneka ragam bentuknya (polyform) dan banyak macam sumbernya. Hanya saja hakikat kekuasaan dalam berbagai bentuk itu tetap sama, yaitu kemampuan seseorang untuk memaksakan kehendaknya atas pihak lain. Di samping bentuk perwujudannya

\footnotetext{
${ }^{8}$ Sebagai bukti, bila kekuasaan tidak berpihak kepada penegakan hukum, maka akan terjadi "kekacauan" dalam semua aspek, seperti yang paling parah di Indonesia adalah penegakan hukum dalam masalah pemberantasan korupsi. Achmad Ali, menyatakan: "... Indonesia dapat dimasukkan sebagai negara paling aneh di dunia, karena sebagai negara yang termasuk paling korup di dunia, justru paling sedikit koruptor yang berhasil dijebloskan ke balik tirai penjara oleh Law enforcement kita". Lihat Achmad Ali, Keterpurukan Hukum di Indonesia..., 19.

9 Pakar hukum di Indonesia yang paling intens membicarakan masalah hukum dan kekuasaan adalah Mochtar Kusumaatmadja, dalam dua bukunya "Hukum, Masyarakat, dan Pembinaan Hukum Nasional" (Bandung: Lembaga Penelitian Hukum dan Kriminologi, Fakultas Hukum UNPAD, 1976); dan "Fungsi Pengembangan Hukum dan Pembangunan Nasional". (Bandung: Lembaga Penelitian Hukum dan Kriminologi, Fakultas Hukum UNPAD, t.th). Dalam dua buku ini, Mochtar mengupas secara panjang lebar bagaimana hubungan dan ketergangungan hukum dengan kekuasaan, begitu juga kekuasaan tanpa kendali hukum akan terjadi kelaliman.
} 
serta sumber-sumber yang berlainan, kekuasaan itu menurut pengamatan sejarah mempunyai suatu sifat khas, yaitu ia cenderung merangsang pemiliknya untuk berkuasa lagi.

Hingga sekarang, kita baru meneliti fenomena kekuasaan itu sendiri (an-sich) dalam hubungannya dengan si pemilik kekuasaan. Sikap pihak orang yang dikuasai turut menentukan kualitas kekuasaan yang berlaku atas dirinya. Jika diterima dan didukung, kekuasaan itu merupakan wibawa. Kekuasaan yang demikian tidak banyak memerlukan paksaan (kekuatan) dalam penggunaannya karena kekuatan itu diperoleh dari (dukungan) yang dikuasai itu sendiri. Semakin kecil dukungan itu (artinya: semakin sedikit yang dikuasai penerima kekuasaan di atasnya) untuk pelaksanannya, akhirnya akan berubah menjadi penggunaan kekerasan semata-mata. Kekuasaan yang demikian tidak dapat tahan lama karena perlawanan (sebagai kebalikan dari dukungan) akan bertambah sedemikian rupa sehingga tidak akan dapat dikendalikan lagi dengan kekuatan senjata.

Kekuasaan itu sendiri baik atau buruk, bergantung bagaimana kita menggunakannya. Ia merupakan suatu unsur yang mutlak bagi kehidupan masyarakat yang tertib, bahkan setiap bentuk organisasi yang teratur. Akan tetapi karena sifat-sifat dan hakikatnya, kekuasaan itu -untuk dapat bermanfaat- harus ditetapkan ruang lingkup, arah, dan batas-batasnya. Untuk itu, dibutuhkan hukum. Sekali ditetapkan, hendaknya pengaturan kekuasaan dipegang teguh. Inilah inti pengertian bahwa kekuasaan itu harus tunduk kepada hukum.

Ada dua hal yang penting dan perlu diperhatikan dalam hal kekuasaan, karena kompleksnya kekuasaan sebagai pengatur kehidupan masyarakat ini. Dua hal tersebut yaitu soal (1) watakwatak dan sifat yang harus dimiliki pemegangnya, dan soal (2) sikap yang dikuasai.

Mengingat sifat dan hakikat kekuasaan, jelas kiranya bahwa tidak semua orang dengan begitu saja dapat diserahi kekuasaan. Ia harus dipersiapkan untuk itu. Seorang pemegang kekuasaan harus 
memiliki semangat mengabdi kepada kepentingan umum (sense of public service).

Mengenai sikap yang dikuasai, dapat dikemukakan bahwa pada satu pihak, ia mempunyai kewajiban untuk tunduk kepada penguasa (the duty of civil obedience), tetapi pada pihak lain, ia pun harus sadar akan hak-haknya sebagai anggota masyarakat. Sebab, hanya dengan demikian ia bisa menggunakan jaminan-jaminan yang diberikan hukum, yang tidak hanya untuk melindungi dirinya sendiri, tetapi juga untuk menyelamatkan masyarakat serta si penguasa dari kehancuran.

Pendeknya, si penguasa maupun si rakyat harus dididik untuk memiliki kesadaran kepentingan umum (public spirit). Kesemuanya ini memerlukan pendidikan yang terarah dan sistematis yang tidak hanya terbatas pada sekolah. Ia meliputi lembaga-lembaga kehidupan masyarakat (social institution), termasuk lingkungan keluarga. Hasilnya tidak dapat kita harapkan lebih cepat dari satu generasi. ${ }^{10}$ Seperti juga halnya dengan pendidikan lainnya, pemberian teladan oleh pemukapemuka masyarakat jauh lebih berguna daripada berpuluh-puluh khotbah atau petuah.

Berdasarkan uraian pemikiran tadi, akan dikemukakan pendapat mengenai dua hal, yaitu: (1) Sikap mental warga negara Indonesia terhadap pihak berkuasa dalam hubungannya dengan perkembangan hukum (termasuk memasukkan nilai-nilai hukum Islam), dan (2) Problematika yang perlu diteliti dalam rangka permasalahan yang berhubungan dengan perkembangan hukum.

Tentang hal pertama, jelas kiranya bahwa di samping menaati pihak yang berkuasa selama penguasa bertindak dalam batasbatas wewenangnya, maka sesuai dengan kewajibannya sebagai warga negara yang baik harus mengetahui dan -apabila perlu-

\footnotetext{
${ }^{10}$ Ide pembenahan sistem kekuasaan yang melibatkan rakyat dan pemimpin harus bersamaan dan sejalan, sudah digagas sejak al-Ghozali dan secara tegas Ibn Taimiyah menulis khusus buku dengan judul al-Siyâsah Syariyyah fî Ishlah al-Râii wa al-Râliyyah, (Beirut: Dâr al-Kutûb al-Islâmiyyah, I409 H/I988 M).
} 
menuntut hak-hak yang diberikan kepadanya oleh undangundang dan hukum. Hanya dengan demikian, ia dapat menjalankan kewajibannya sebagai warga negara yang baik, dalam arti turut menjaga ketertiban warga negara, baik ia sebagai penguasa atau rakyat. Sikap yang demikian lebih baik daripada sikap yang menurut saja secara pasif, walaupun yang terakhir tentunya lebih mudah.

Yang pasti, warga negara yang demikian (menurut saja secara pasif) tidak menjalankan kewajiban-kewajibannya secara sepenuhnya. Sikap yang demikian barangkali cukup bagi seorang kawula negara (subyek) dari sebuah daerah jajahan yang tidak bertanggung jawab untuk kemajuan negerinya. Sikap demikian tidak memadai bagi seorang warga negara (citizen) suatu negara yang merdeka.

Kesulitan bagi suatu bangsa yang sedang membangun, lebihlebih lagi suatu negara yang baru merdeka adalah merubah sikap dari pasif menjadi aktif. Ia harus meninggalkan sikap terhadap pihak penguasa yang sudah terbiasa menjajah dan menggantinya dengan sikap yang baru. Sikap yang baru itu (aktif) jauh lebih susah daripada sikap lama (pasif). Tapi, itulah memang konsekuensi menjadi bangsa yang merdeka.

Penyesuaian tadi tidak saja pada warga negara. Penguasa pun perlu, karena bagi si penguasa, respon yang pasif terhadapnya barangkali lebih menyenangkan. Akan tetapi, penguasa yang berpandangan jauh, bijaksana, dan patriotik sudah barang tentu akan membantu tumbuhnya sikap yang aktif terhadap kekuasaannya, karena ini akhirnya (in the long run) akan membantu juga. ${ }^{11}$

Masalah yang perlu diteliti dalam hal yang berhubungan dengan hukum, di samping masalah dasar yang secara singkat

II Berangkat dari ide itulah sepertinya gagasan reformasi di tahun 1998 dipilih oleh bangsa Indonesia dalam mengganti kejenuhan rezim Soeharto yang berkuasa sedemikian panjang dan melahirkan Kolusi, Korupsi dan Nepotisme yang cukup mengakar, sampai sekarang pun sulit diberantas, atau bahkan menyentuh sekalipun sudah ada KPK (Komisi Pemberantasan Korupsi). 
telah disinggung di atas, yang paling mendesak adalah keadaan pendidikan hukum dewasa ini. Sudahkah ia memenuhi kebutuhan penegakan hukum? Tepatkah sudah pengarahannya, dan cukup relevankah ia pada masalah-masalah yang dihadapi masyarakat Indonesia sekarang?

Di samping masalah-masalah dasar tadi, diperlukan perkembangan hukum positif yang berlaku, agar ia dapat lebih memenuhi kebutuhan masyarakat terhadap kepastian di segala bidang, khususnya bagi umat Islam yang mayoritas di negeri ini.

Deskripsi di atas menunjukkan betapa sangat terikatnya antara hukum dan kekuasaan. Hanya saja belum ada jaminan bahwa hukum akan efektif apabila ditopang oleh kekuasaan, dan kekuasaan akan adil, atau tidak sewenang-wenang, bila dipagari oleh hukum. Karena, kekuasaan dan hukum dalam realitasnya; hak dan kewajiban apapun pelaksanaannya sangat bergantung pula dari proses kelahiran kekuasaan dan prosedur pembentukan hukum. Apakah kelak hukum itu dapat menjamin rasa keadilan masyarakat secara kâffah (utuh dan menyeluruh) bukan hanya memenuhi standar "kepastian hukum" saja, ataukah hanya sekedar pelengkap normatif semata.

\section{Sistem Politik Islam di Indonesia}

Dalam kenyataan, ternyata karakteristik produk hukum senantiasa berubah sejalan dengan perkembangan sistem politik atau "konfigurasi politik" (meminjam istilah yang disebutkan Moh. Machfud M.D.). Hal ini menunjukkan bahwa konsistensi kecenderungan perubahan karakter itu sangat dipengaruhi oleh konfigurasi politik tersebut. Perubahan responsif senantiasa muncul dari sistem politik yang demokratis, sedang watak konservatif lahir dari konfigurasi politik yang otoriter. ${ }^{12}$ Dengan demikian, ketidakpastian sistem politik di Indonesia sangat

12 Moch. Machfud, M.D., Politik Hukum di Indonesia, (Jakarta: LP3ES, 200I). 
berpengaruh terhadap perwatakan dan karakteristik hukum nasional. ${ }^{13}$

Dalam paradigma lama, politik merupakan istilah mulia dalam upaya membangun kemaslahatan bersama, tapi sekarang politik adalah senjata untuk mencapai dan menduduki kekuasaaan bahkan mempertahankannya dengan segala cara. Sebagai akibat dari kondisi tersebut, di Indonesia sekarang hukum sedang mengalami ujian krisis yang cukup parah.

Sejalan dengan era yang serba kompetitif, kepentingan umat Islam dalam berjuang mentransformasikan nilai-nilai ideal hukum Islam yang menjadi tugas dari keimanan mereka, perlu diselaraskan dengan konsensus final bahwa Negara Kesatuan Republik Indonesia sudah menjadi rumah bernegara umat Islam Indonesia. Perjuangan umat Islam harus dalam bentuk mengisi celah-celah kekosongan hukum positif yang belum akomodatif dengan cita-cita ajaran Islam bukan membongkar rumah yang sudah permanen. Sepertinya ada keberuntungan umat Islam Indonesia untuk mewujudkan cita-cita perjuangan tersebut, karena paling tidak ada tiga faktor yang menopangnya, yaitu:

1. Setelah era reformasi diperbolehkan kembali umat Islam mendirikan partai politik yang berbasis ideologi keislaman, walaupun tentu harus ada penyesuaian dengan dasar negara dan sistem konstitusi yang sudah disepakati sebagai pilar bernegara. Dengan adanya peluang ini maka lahirlah partaipartai yang berasaskan keislaman atau mereka menamakan partai dakwah seperti Partai Keadilan Sejahtera (PKS), Partai Persatuan Pembangunan (PPP), Partai Bulan Bintang (PBB), atau partai-partai yang berbasis ormas keagamaan mayoritas umat Islam seperti Partai Kebangkitan Bangsa (PKB) yang erat dengan Nahdlatul Ulama (NU) atau Partai Amanat Nasional (PAN) yang erat dengan Muhammadiyah, dan yang lain-lain. Terlepas keberadaan partai-partai itu belum

${ }^{13}$ Ali mengistilahkan keterpurukan hukum Nasional. Lihat Achmad Ali, Keterpurukan Hukum di Indonesia...., 19. 
Jeje Abdul Rojak

memberi kontribusi maksimal terhadap perjuangan umat Islam, atau bahkan terjebak juga sebagian oknumnya dalam praktik tercela, seperti korupsi. Akan tetapi, cukup menunjukkan sebagai wadah perjuangan umat Islam dalam kancah politik.

Sedikit banyak dari adanya partai-partai tersebut suara-suara untuk memberikan ruang terhadap idealisme ajaran Islam (baca: hukum Islam), sepertinya cukup ada.

2. Keberadaan ormas keagamaan umat Islam seperti NU, Muhammadiyah, Persis, Majelis Ulama Indonesia (MUI), dan lain-lain, juga di dalamnya memperjuangkan bagaimana hukum Islam bersimbiosis dengan kehidupan masyarakat, berbangsa dan bernegara. Kajian-kajian masalah hukum cukup instan dilakukan, bahkan dalam organisasi keagamaan tersebut mempunyai wadah khusus yang mengkaji masalah hukum.

Dengan adanya organisasi massa keagamaan ini jelas praktik hukum Islam berlaku paling tidak di kalangan anggota organisasi tersebut.

3. Adanya lembaga pendidikan formal yang secara khusus diberikan ruang yang cukup lebar untuk mempelajari hukum Islam secara mendalam dari berbagai perspektif. Lembaga pendidikan itu dimulai dari tingkat dasar, yaitu Madrasah Ibtidaiyah sampai perguruan tinggi dengan jenjang strata satu, dua, dan strata tiga.

Dari ketiga lembaga tersebut, sudah cukup tempat perjuangan umat Islam dalam mengisi kekosongan hukum Islam yang memberi kepastian hukum bagi umat Islam. Tinggal bagaimana dari gerakan tersebut berjuang di ruang legislasi dan promosi di masyarakat agar hukum Islam mempunyai daya pikat untuk memperbaiki penegakan hukum yang carut marut.

\section{Peletakan Hukum Islam dalam Sistem Hukum Nasional}

Posisi hukum Islam dalam sistem hukum nasional kita sampai saat ini masih belum jelas. Jika mengacu pada teori 
pluralisme hukum dalam sistem hukum Indonesia juga terkadang kuat, tapi terkadang juga lemah.

Selama ini penyisipan hukum Islam masih menggunakan dua pola, ada hukum Islam yang secara implisit dimasukkan substansinya tanpa harus dicanangkan ke publik bahwa aturan tersebut adalah hukum Islam, misalnya yang terjadi dalam ranah hukum perkawinan. Namun ada pola lain yang secara eksplisit disebutkan sebagai hukum Islam, misalnya dalam lapangan ekonomi syari'ah.

Bila melihat sejarah, hukum Islam sebenarnya sudah ada dan telah mengakar dalam masyarakat Indonesia. Keberadaan hukum Islam di Indonesia telah ada semenjak agama Islam datang ke Indonesia dan memiliki peranan penting bagi kehidupan masyarakat Indonesia hingga sekarang. Pada saat itu, hukum Islam berdampingan dengan hukum adat. ${ }^{14}$ Namun demikian, hukum Islam belum menjadi hukum yang berdiri sendiri di Indonesia. Ia hanya dilaksanakan oleh pemeluknya tanpa kedudukan yang pasti. Oleh sebab itu, hukum Islam membutuhkan kedudukan pasti dalam sistem hukum nasional.

Mulai dari zaman kerajaan, zaman kolonialisasi hingga kemerdekaan, perkembangan hukum Islam di Indonesia selalu diwarnai dengan kepentingan politik. Terutama saat bangsa Belanda datang ke Indonesia untuk menguasai Indonesia. Mereka ingin menerapkan hukum Belanda di Indonesia. Namun, karena di Indonesia telah ada hukum Islam dan hukum adat, maka hukum

\footnotetext{
${ }^{14}$ Sebagaimana yang dikemukakan oleh Hazairin: "Hukum agama masih terselip dalam hukum adat yang memberikan tempat dan persandaran kepadanya, tetapi sekarang kita lihat hukum agama itu sedang bersiap hendak membongkar dirinya dari ikatan adat itu. Arti istimewanya hukum agama itu ialah bahwa hukum agama itu bagi rakyat Islam dirasakannya sebagai bagian dari perkara imannya. Jika berhasil hukum agama itu melepaskan persandarannya kepada suatu undang-undang, sebagaimana juga hukum adat itu bagi berlakunya secara resmi mempunyai persandaran pada undang-undang." Lihat Rudi M Rizky (ed), Refleksi Dinamika Hukum: Rangkaian Pemikiran dalam Dekade Terakhir, (Jakarta: Perum Percetakan Negara RI, 2008), 262. Lebih lanjut menurut Hazairin, seharusnya berlakunya hukum Islam untuk orang Islam di Indonesia tidak disandarkan pada hukum adat, tetapi pada penunjukan peraturan perundang-undangan tersendiri, seperti halnya yang terjadi pada hukum adat, dimana hukum adat berlaku berdasarkan dukungan peraturan perundang-undangan.
} 
Belanda tidak dapat diterapkan secara penuh. Mereka kemudian membuat penggolongan hukum.

Pada awalnya, Belanda mengakui keberadaan hukum Islam di masyarakat, tetapi perkembangan hukum Islam menjadi terhambat karena adanya kepentingan kolonialisasi. Bahkan kemudian, Belanda ingin menghilangkan pengaruh Islam dari orang Indonesia karena menurut mereka hukum Islam menjadi penghambat penguasaan Belanda di Indonesia. Namun Belanda tidak dapat menghapus hukum Islam dari orang Indonesia, karena akan mendapat pertentangan hebat dari bumi putera dan agama Islam. Oleh karena itu, mereka membuat penggolongan hukum tersebut.

Penggolongan hukum yang dibuat pemerintah kolonial menjadikan hukum terbagi-bagi menjadi hukum yang berlaku bagi golongan pribumi, hukum yang berlaku bagi golongan eropa dan timur jauh, dsb. Dalam hal ini, hukum Islam diterapkan bagi pribumi yang menganut agama Islam. Tidak hanya melakukan penggolongan hukum, pihak Belanda pada saat itu meminta D.W. Freijer untuk menyusun suatu compendium (intisari/ringkasan) yang memuat hukum perkawinan dan kewarisan dalam Islam. ${ }^{15}$ Ringkasan tersebut kemudian digunakan oleh pengadilan untuk menyelesaikan sengketa-sengketa di kalangan umat Islam.

Sampai saat itu, keberadaan hukum Islam terlihat dari eksistensi pengadilan agama Islam dalam mengadili sengketasengketa di lapangan hukum perdata. Kebijakan ini terus dipertahankan dan dikukuhkan setelah kemerdekaan Indonesia. Jika terjadi sengketa dalam hukum keluarga misalnya perceraian, maka kewenangan ini berangkat dari subjek-subjek sengketa yang beragama Islam. Artinya, kewenangan bersifat subjektif (bergantung pada subjek yang terlibat). Sementara untuk sengketa di ranah ekonomi syariah, faktor subjektif ini sudah dilampaui. Sehingga, Pengadilan Agama tetap memiliki kewenangan absolut,

15 Mohammad Daud Ali, Hukum Islam: Pengantar Ilmu Hukum dan Tata Hukum Islam di Indonesia, (Jakarta: Rajawali Press, 1990), 236. 
sekalipun pihak yang terikat akad tidak semuanya beragama Islam.

Hal ini dipertegas dengan putusan Mahkamah Konstitusi Nomor 93/PUU-X/2012 berkenaan dengan pengujian atas Pasal 55 Undang-Undang Perbankan Syariah. Pasal ini merepresentasikan politik hukum saat ini terkait pemosisian hukum Islam dalam konstelasi sistem hukum nasional. Pada Undang-Undang Nomor 21 Tahun 2008 ini ditetapkan, para pembentuk Undang-Undang tetap menempatkan hukum Islam sebagai subordinat dari hukum negara (hukum nasional). ${ }^{16}$

Peradilan Agama masih dipandang sebagai lingkungan khusus untuk mengadili perkara-perkara yang berkenaan dengan internal orang Islam dan sebagian besar masih terfokus pada permohonan penetapan dan putusan sengketa-sengketa di dalam hukum keluarga. Ketika sengketa perbankan syariah dimasukkan ke dalam kewenangan absolut peradilan agama itu, para pihak ternyata masih diberi kemungkinan memilih forum penyelesaian sengketanya di lingkungan peradilan umum (peradilan negeri). Hal ini bisa dilakukan apabila akad para pihak menghendaki demikian. Walaupun ada pilihan forum (choice of forum) di pengadilan negeri, misalnya pilihan hukum (choice of law) adalah hukum Islam dengan berdasarkan prinsip-prinsip syariah.

Upaya-upaya untuk mengembalikan kedudukan hukum Islam pun terus dilakukan sebelum maupun setelah kemerdekaan. Pada masa pemerintahan Jepang menjelang kemerdekaan, Badan Penyelidik Usaha Persiapan Kemerdekaan (BPUPKI) merumuskan dasar negara dan menentukan hukum dasar bagi negara Indonesia di kemudian hari. Akhirnya muncullah Pancasila dengan sila pertama berbunyi “Ketuhanan Yang Maha Esa. Pancasila ini yang kemudian menjadi dasar dari sistem hukum nasional.

Sistem hukum tersusun atas sejumlah komponen yang saling berhubungan dan sama-sama mewujudkan suatu keutuhan untuk

${ }^{16}$ Jika memakai skema John Griffiths, skema ini disebut sebagai weak legal pluralism. 
mencapai tujuan hukum tertentu. Sistem hukum nasional merupakan susunan sejumlah komponen hukum yang saling berhubungan dalam suatu negara untuk mencapai tujuan hukum nasional. Komponen-komponen itu dapat berupa struktur, substansi, maupun kultur hukum yang kesemuanya bertujuan mencapai tujuan hukum nasional.

Sistem hukum nasional Indonesia merupakan sistem hukum yang berdasarkan Pancasila dan Undang-Undang Dasar 1945, sehingga setiap bidang hukum yang akan menjadi bagian dari sistem hukum nasional itu wajib bersumber pada Pancasila dan Undang-Undang Dasar 1945. Pancasila menjadi "jantung" dalam sistem hukum nasional karena merupakan filosofi negara. Dimana menurut Pancasila, dengan berpangkal kepada Ketuhanan Yang Maha Esa menyiratkan bahwa ada kewajiban masyarakat Indonesia untuk menjalankan perintah Tuhan yang menurut agama Islam menjalankan syariat Islam. Dengan demikian, hukum Islam mempunyai kedudukan dalam sistem hukum nasional dan dapat turut andil dalam pembangunan hukum nasional.

Sistem Hukum Nasional di Indonesia memiliki urutan yang terdiri dari Pancasila yang berdasarkan UUD 1945, Peraturanperaturan perundang-undangan, Yurisprudensi dan Hukum kebiasaan. ${ }^{17}$

Upaya peletakan dan penyisipan hukum Islam dalam sistem hukum nasional telah dilakukan melalui beberapa hal, diantaranya:

1. Membentuk Kompilasi Hukum Islam. Kompilasi hukum Islam sudah dianggap sebagai hukum positif bagi umat Islam yang berlaku di Indonesia.

2. Membentuk Peradilan Agama berdasarkan Undang-Undang Nomor 7 Tahun 1989 tentang Peradilan Agama.

17 Sunaryati Hartono, Politik Hukum Menuju Satu Sistem Hukum Nasional, (Bandung: Alumni, |99|), 64. 
3. Norma-norma dalam hukum Islam yang dapat dijadikan patokan membentuk suatu hukum nasional sepanjang ia sesuai dengan Pancasila dan Undang-Undang Dasar 1945.

Namun demikian, dalam rangka pembangunan hukum nasional perlu kiranya memperhatikan asas-asas yang terdapat dalam hukum Islam untuk diterapkan dalam peraturan perundang-undangan yang akan diberlakukan untuk masyarakat Indonesia. Karena hukum Islam ini telah mengakar lama dalam masyarakat Indonesia dengan mayoritas penduduk beragama Islam, maka perundang-undangan yang sudah ada dan akan dibuat perlu dikaji untuk senantiasa sejalan dengan norma-norma Islam.

Sistem hukum nasional perlu belajar mandiri dan berkembang, dimana undang-undang dan peraturan warisan kolonial yang sudah tidak digunakan -di negara Belanda-, dapat diganti dengan undang-undang dan peraturan yang lebih sesuai untuk negara kita. Hal ini dapat dilakukan dengan kajian terhadap hukum Islam secara mendalam dengan memperhatikan wawasan kebangsaan. Lembaga legislasi dalam pembentukan hukum nasional juga harus selalu berkoordinasi dengan lembaga-lembaga pengkaji hukum Islam yang ada di Indonesia.

Di samping itu, tiga faktor penopang keberadaan hukum Islam, yaitu partai politik berbasis ideologi keislaman, organisasi masyarakat keagamaan umat Islam dan berbagai lembaga pendidikan baik formal maupun informal perlu berjuang di ruang legislasi dan mempromosikan diri di masyarakat dengan menyisipkan norma-norma dan nilai-nilai Islam dalam berbagai kebijakan yang diterapkan di wilayah masing-masing. Dengan demikian, norma-norma Islam akan terus tumbuh di masyarakat dan tidak akan luntur.

\section{Penutup}

Perjalanan panjang umat Islam berjuang dalam penegakan hukum sebagai wujud tanggung jawab keimanan di hadapan Tuhan, ternyata membutuhkan seni dan berbagai modal 
pendekatan. Penegakan hukum merupakan wujud dari amar ma'ruf nahiy munkar, bagi umat Islam terus dipromosikan tanpa jeda dan tanpa lelah dengan pola yang harus mendapat simpatik dan harmoni bukan dengan cara pemaksaan dan kekerasan. Di sini, strategi dan taktik harus diperankan secara arif. Pendekatan politik hukum inilah cara yang luwes untuk disajikan secara damai.

Keberhasilan pribumi muslim Indonesia mendirikan negara sebagaimana bentuknya sekarang adalah perjuangan final sebagai rumah bernegara mereka. tidak ada lagi gugatan untuk mencari bentuk baru, karena dengan bentuk negara seperti ini sudah merupakan ijtihad umat Islam yang sesuai dengan kultur dan karakteristik bangsa Indonesia yang majemuk. Masalahnya, adalah tinggal mengisi sisi-sisi ruang mana yang perlu diselaraskan dengan cita-cita ajaran Islam atau hukum Islam dari celah-celah berbangsa dan bernegara yang masih kosong.

\section{Daftar Pustaka}

Adinegoro. Pemilihan Umum dan Djiwa Masyarakat di Indonesia. Jakarta: Bulan Bintang, t.t.

Ali, Achmad. Keterpurukan Hukum di Indonesia (Penyebab dan Solusinya). Jakarta: Ghalia Indonesia, 2002.

Ali, Mohammad Daud. Hukum Islam: Pengantar Ilmu Hukum dan Tata Hukum Islam di Indonesia. Jakarta: Rajawali Press, 1990.

Ali, Muhammad Daud. Hukum Islam dan Peradilan Agama (Kumpulan Tulisam). Jakarta: Raja Grafindo Persada, 1997.

Ali, Muhammad Daud. Hukum Islam dan Peradilan Agama. Jakarta: PT Raja Grafindo Persada, 1997.

Amiin, SM. Kodifikasi dan Unifikasi Hukum Nasional. Jakarta: PT. Tribisana, 1978.

Azizy, Achmad Qodri Abdullah. Eklektisisme Hukum Nasional Kompetisi antara Hukum Islam dan Hukum Umum. Yogyakarta: Gama Media, 2002.

Hamzah, Imron dan Choirul Anam. Gus Dur Diadili Kiai-Kiai. Surabaya: Jawa Pos, 1989. 
Hartono, Sunaryati. Politik Hukum Menuju Satu Sistem Hukum Nasional. Bandung: Alumni, 1991.

Hartono, Sunaryati. Politik Hukum Menuju Satu Sistem Hukum Nasional. Bandung: Alumni, 1991.

Kusumaatmadja, Mochtar. Hukum, Masyarakat dan Pembinaan Hukum Nasional. Bandung: Lembaga Penelitian Hukum dan Kriminologi, Fakultas Hukum Universitas Padjajaran, 1976.

M.D., Moh. Mahfud. Politik Hukum di Indonesia. Jakarta: LP3ES, 2001.

Rizky, Rudi M (ed). Refleksi Dinamika Hukum: Rangkaian Pemikiran dalam Dekade Terakhir. Jakarta: Perum Percetakan Negara RI, 2008.

Taimiyah, Ibn. al-Siyasah Syar'iyyah fi Ishlah al-Ra'i wa al-Ra'iyyah. Beirut: Dâr al-Kutub al-Islamiyyah, 1409 H/1988 M.

Zahro, Ahmad. Tradisi Intelektual NU, Lajnah Bahtsul Masail 19261999. Yogyakarta: LkiS, 2004. 